\title{
Effect of dietary taurine supplementation on the growth and blood physiological parameters of juvenile pirarucu
}

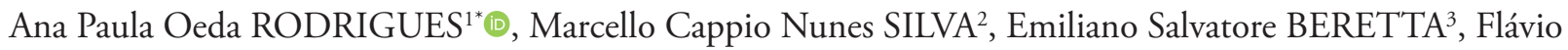 \\ Augusto Leão da FONSECA ${ }^{2,4}$, Giuliana PARISI³, Luís Eugênio Castanheira da CONCEIÇÃO5, Ligia Uribe \\ GONÇALVES ${ }^{2,6}$ \\ Empresa Brasileira de Pesquisa Agropecuária, Embrapa Pesca e Aquicultura, CP 90, CEP 77008-900, Palmas, TO, Brazil \\ 2 Universidade Nilton Lins, Programa de Pós-Graduação em Aquicultura, Parque das Laranjeiras, Av. Prof. Nilton Lins 3259, Flores, CEP 69058-030, Manaus, AM, Brazil \\ Università degli Studi di Firenze, Dipartimento di Scienze e Tecnologie Agrarie, Alimentari, Ambientali e Forestali Piazzale delle Cascine, 18, 50144 Firenze, Italy \\ ${ }^{4}$ Instituto Federal do Amazonas - Campus Manaus Zona Leste, Av. Cosme Ferreira 8045, Gilberto Mestrinho, CEP 69086-475, Manaus, AM, Brazil \\ SPAROS Área Empresarial de Marim, Lote C, CEP 8700-221, Olhão, Portugal \\ 6 Instituto Nacional de Pesquisas da Amazônia, Coordenação de Tecnologia e Inovação, Av. André Araújo 2936, Petrópolis, CEP 69067-375, Manaus, AM, Brazil \\ * Corresponding author: anapaula.rodrigues@embrapa.br; (D) https://orcid.org/0000-0002-2766-657X
}

\section{ABSTRACT}

For some fish species, dietary taurine supplementation has been proven necessary in feeds with considerable utilization of vegetable proteins to substitute fishmeal. Pirarucu, Arapaima gigas feeds mainly on taurine-rich animal items in nature, therefore this study aimed to evaluate the effect of dietary taurine supplementation $(0,0.5,1,1.5$ and $3 \%)$ on the growth and blood physiological parameters of juvenile pirarucu. A commercial feed was utilized as the basal diet for the experimental diets. Three hundred fish $(20.8 \pm 2.3 \mathrm{~g})$ were randomly distributed in 15 tanks and fed for 28 days. At the end of the trial, dietary taurine supplementation did not affect fish growth, feed consumption and feed efficiency. The original amounts of taurine $(0.18 \%)$ and methionine $(1.13 \%)$ in the commercial feed $(0 \%$ taurine diet) apparently sufficed to promote adequate pirarucu growth, with no variation noted in the main blood physiological parameters. Further studies to assess whether taurine is conditionally essential for the pirarucu fed methionine-deficient diets are needed to elucidate the functionality of this nutrient for the studied species.

KEYWORDS: fishmeal, vegetable proteins, methionine, Arapaima gigas

\section{Efeito da suplementação de taurina sobre o crescimento e parâmetros fisiológicos sanguíneos de juvenis de pirarucu}

\section{RESUMO}

Para algumas espécies de peixe, a suplementação de taurina na dieta tem-se mostrado necessária em dietas com grande utilização de proteínas vegetais em substituição à farinha de peixe. Na natureza, o pirarucu, Arapaima gigas se alimenta de itens animais ricos em taurina, portanto este estudo avaliou o efeito da suplementaçáo de taurina $(0 ; 0,5 ; 1 ; 1,5$ e 3\%) sobre o crescimento e parâmetros fisiológicos sanguíneos de juvenis da espécie. Uma ração comercial foi utilizada como dieta basal para as dietas experimentais. Trezentos peixes $(20,8 \pm 2,3 \mathrm{~g})$ foram aleatoriamente distribuídos em 15 tanques e alimentados durante 28 dias. Ao final do ensaio, a suplementaçáo de taurina nas dietas não afetou crescimento, consumo de alimento e eficiência alimentar dos peixes. As quantidades iniciais de taurina $(0,18 \%)$ e metionina $(1,13 \%)$ da raçáo comercial (dieta $0 \%$ taurina) foram aparentemente suficientes para promover o crescimento adequado do pirarucu sem alteraçáo dos principais parâmetros fisiológicos do sangue. Futuros estudos que avaliem se a taurina é condicionalmente essencial para pirarucu alimentado com dietas deficientes em metionina são necessários para elucidar a funcionalidade deste nutriente para a espécie.

PALAVRAS-CHAVE: farinha de peixe, proteínas vegetais, metionina, Arapaima gigas 


\section{INTRODUCTION}

Taurine (2-aminoethanesulfonic acid) is one of the end products of sulfur amino acids metabolism that is synthesized from methionine via cysteine. It performs an antioxidant and membrane protective function, and also acts in cell osmoregulation, bile salt conjugation, lipid metabolism, glycemic control and immunoregulation (Huxtable 1992; El-Sayed 2014; Salze and Davis 2015; Hoseini et al. 2018). It is abundant in animal protein sources, particularly those of marine origin, and its concentration is low or practically null in plant sources (Spitze et al. 2003). With vegetable protein being increasingly used as a substitute for fishmeal in feed formulations for aquatic organisms, dietary taurine supplementation has been necessary to meet this requirement (Salze and Davis 2015). This need for supplementation varies with species, fish developmental stage and diet composition (e.g. Gaylord et al. 2006; 2007; Kim et al. 2008; Lim et al. 2013; Peterson and Li 2018).

Pirarucu (Arapaima gigas) is an endemic fish of the Amazon basin of great socio-economic importance for the region (Núńez et al. 2011; Farias et al. 2015). Characteristics like obligatory air breathing, rapid growth, mild-flavored meat and high commercial value explain the growth of its captive production in recent years, and make pirarucu one of the most promising species for aquaculture development in the Amazon region (Lima et al. 2015). It is a carnivorous fish that feeds mainly on insects, crustaceans and mollusks in early stages (Queiroz 2000; Oliveira et al. 2005), and it preys on fish when its size exceeds $50 \mathrm{~cm}$ (Queiroz 2000; Carvalho et al. 2018). A comparative analysis of the muscle-tissue amino acid profile from wild and farmed pirarucu indicated a higher taurine concentration in wild individuals (3- to 5-fold higher) (Rodrigues et al., unpublished data). The same variation was not observed between farmed and wild salmon, Salmo salar fillets (Gormley et al. 2007), which may be owed to differences in diet composition between both species. While the natural diet of pirarucu contains taurine-rich food items, commercial feeds employed in pirarucu farming are formulated generically for carnivorous fish and not specifically for the species' nutrient requirements, having a varied and seasonal combination of animal and plant ingredients (Cyrino et al. 2010). Considering this fact and the higher level of taurine in wild pirarucu muscle in comparison to farmed pirarucu, studies that evaluate the function of this nutrient for the species are necessary. We evaluated the effect of taurine supplementation in a commercial diet on the growth and blood physiological parameters of juvenile pirarucu.

\section{MATERIAL AND METHODS}

\section{Experimental diets}

The experiment evaluated five taurine supplementation levels $(0,0.5,1,1.5$ and $3 \%)$ in a completely randomized design with three replications. A commercial feed (Aquaxcel ${ }^{\circ}$; $45 \%$ crude protein, $12 \%$ ether extract, $1.5 \mathrm{~mm}$ ) was used as the basal diet for the experimental diets and ground through a $500-\mu \mathrm{m}$ mesh. The amount of included taurine (Sigma Chemical Co. St. Louis, MO, USA) considered the diet amino acid profile, which was already composed of $0.18 \%$ of taurine (Table 1 ). Therefore, $0.35,0.82,1.28$ and $2.65 \%$ of taurine was included to obtain $0.5,1,1.5$ and $3 \%$ taurine experimental diets, respectively. To minimize diet taurine leaching into water during fish feeding, 5.2\% gelatin was added to the experimental diets. After dry ingredient homogenization, $35 \%$ of hot water was added. The mixture was pelleted in a meat grinder $(4 \mathrm{~mm})$ and dried in a forced air oven at $65^{\circ} \mathrm{C}$ for $24 \mathrm{~h}$. The experimental diets were analyzed

Table 1. Analyzed composition of the experimental diets used in the taurinesupplementation trial for juvenile pirarucu, Arapaima gigas.

\begin{tabular}{lccccc|}
\hline \multirow{2}{*}{ Composition ( $\mathbf{~ k g}^{-1}$ diet) } & \multicolumn{5}{c}{ Taurine supplementation levels (\%) } \\
\cline { 2 - 6 } & $\mathbf{0}$ & $\mathbf{0 . 5}$ & $\mathbf{1 . 0}$ & $\mathbf{1 . 5}$ & $\mathbf{3 . 0}$ \\
\hline Dry matter & 933 & 935 & 935 & 935 & 942 \\
\hline Crude protein & 462 & 468 & 472 & 468 & 471 \\
\hline Ether extract & 85 & 91 & 89 & 96 & 97 \\
\hline Ash & 84 & 85 & 87 & 89 & 85 \\
\hline Essential amino acids & & & & & \\
\hline Arginine & 30.1 & 30.7 & 31.3 & 30.9 & 32.3 \\
\hline Histidine & 10.2 & 10.5 & 11.0 & 10.8 & 11.0 \\
\hline Isoleucine & 19.7 & 20.1 & 19.7 & 19.6 & 19.4 \\
\hline Leucine & 30.5 & 30.9 & 30.8 & 30.5 & 29.9 \\
\hline Lysine & 29.1 & 28.6 & 29.4 & 29.1 & 28.9 \\
\hline Methionine & 11.3 & 10.9 & 11.6 & 11.1 & 11.1 \\
\hline Phenylalanine & 19.9 & 20.0 & 19.9 & 19.9 & 19.7 \\
\hline Threonine & 18.6 & 18.7 & 18.9 & 18.8 & 18.9 \\
\hline Valine & 23.1 & 24.4 & 23.7 & 23.7 & 22.8 \\
\hline Non-essential amino acids & & & & & \\
\hline Alanine & 28.5 & 28.6 & 28.5 & 28.4 & 28.3 \\
\hline Aspartic acid & 42.4 & 41.9 & 42.4 & 42.2 & 43.1 \\
\hline Glycine & 38.6 & 38.6 & 38.3 & 38.4 & 38.1 \\
\hline Glutamic acid & 65.5 & 63.5 & 66.7 & 66.6 & 67.0 \\
\hline Cysteine & 7.0 & 5.3 & 7.4 & 6.2 & 6.2 \\
\hline Tyrosine & 12.9 & 14.7 & 14.6 & 13.6 & 13.9 \\
\hline Proline & 31.9 & 32.2 & 31.8 & 31.8 & 31.5 \\
\hline Serine & 24.3 & 24.3 & 24.7 & 24.9 & 24.6 \\
\hline Taurine & 1.8 & 5.1 & 9.8 & 15.6 & 31.1 \\
\hline & & & & \\
\hline
\end{tabular}


according to AOAC (1990) for dry matter (method 930.15), ash (942.05), crude protein $(\mathrm{N} \times 6.25$; 988.05) and ether extract (petroleum ether; 920.39) (Table 1). The amino acid profile, including taurine, was analyzed by high-performance liquid chromatography (HPLC) (White et al. 1986) (Table 1).

\section{Fish handling}

Juvenile pirarucu were purchased from a commercial fish farm (Primavera de Rondônia-RO, Brazil) and previously acclimated to laboratory conditions for 30 days. Following acclimation, fish were individually weighed and measured (weight: $20.8 \pm 2.3 \mathrm{~g}$; total length: $14.5 \pm 0.9 \mathrm{~cm}$ ) and randomly distributed in 15 circular tanks ( $500 \mathrm{~L}$ each) with a continuous water flow (20 fish per tank; $225 \mathrm{~L} \mathrm{~h}^{-1}$ ). Fish were acclimated to the experimental conditions for one week on the basal diet with no taurine supplementation. The experimental diets were provided three times per day until apparent satiety (09:00, 13:00 and 17:00h) for 28 days (Rodrigues et al. 2019). The experimental time considered the high growth rates of the species according to the NRC (2011) recommendation and to the results obtained from previous experiments done in our laboratory. The photoperiod (approximately 12L:12D) and water temperature were maintained under natural conditions. Temperature $\left(29.5 \pm 1.5^{\circ} \mathrm{C}\right)$, dissolved oxygen $(7.4 \pm 0.7$ $\left.\mathrm{mg} \mathrm{L}{ }^{-1}\right), \mathrm{pH}(7.00 \pm 0.34)$, total ammonia $\left(0.09 \mathrm{mg} \mathrm{L}^{-1}\right)$, and water nitrite $\left(0.04 \mathrm{mg} \mathrm{L}^{-1}\right)$ were kept within the values recommended for pirarucu development (Cavero et al. 2003a, b; Núñez et al. 2011).

\section{Growth and blood parameters}

At the end of the experiment, fish were fasted for $24 \mathrm{~h}$ and individually weighed. The following growth parameters were evaluated:

- Weight gain $(\mathrm{g})$ = final weight - initial weight;

- Daily weight gain $\left(\mathrm{g} \mathrm{day}^{-1}\right)=$ weight gain/feeding period;

- Specific growth rate $\left(\%\right.$ day $\left.^{-1}\right)=[(\ln$ final weight $-\ln$ initial weight $) /$ feeding period] $\times 100$;

- Feed conversion ratio $=$ feed intake $($ as fed basis $) /$ weight gain;

- Survival $(\%)=($ final number of fish/initial number of fish) $\times 100$;

- Protein efficiency ratio $=($ weight gain $(\mathrm{g}) /$ consumed crude protein $(\mathrm{g})$;

- Feed consumption $=$ total amount of feed consumed per fish (g).

To evaluate the hematological and biochemical parameters, blood samples from five fish per tank were collected by puncturing the caudal vein using syringes rinsed with 10\% EDTA. Whole blood was utilized for the hematocrit (Goldenfarb et al. 1971) and hemoglobin (Blaxhall and Daisley 1973) analyses. Glucose, total protein, cholesterol, triglycerides and albumin determinations were made after whole blood centrifugation $\left(1400 \mathrm{~g}\right.$ for $10 \mathrm{~min}$ at $\left.4^{\circ} \mathrm{C}\right)$ using commercial kits (Labtest Diagnóstica SA, Lagoa Santa, MG, Brazil) and by spectrophotometry.

\section{Data analysis}

The response variables to taurine supplementation in the diet were analyzed through regression models using the coefficient of determination $\left(\mathrm{R}^{2}\right)$ and Akaike's Information Criterion (AIC) for determination of the "best-fit" model (CurveExpert Pro 2.6 software). Data were also analyzed by one-way ANOVA, followed by Tukey's test $(\mathrm{P}<0.05)$ to illustrate the magnitude of differences among means (TIBCO, Statistica 13.3). The homoscedasticity (Levene's test) and normality (Shapiro-Wilk's test) of residues were checked and confirmed. Data are expressed as mean \pm standard deviation.

\section{Legal aspects}

The experiment complied with Brazilian legislation for the care and use of animals for educational and scientific purposes (Concea - protocol CEUA/INPA 16/2016), and with Sistema Nacional de Gestáo do Patrimônio Genético e do Conhecimento Tradicional Associado (AA4F2B0).

\section{RESULTS}

The "best-fit" model found in the regression analysis was the quadratic model, showing low values for the coefficient of determination $\left(\mathrm{R}^{2}\right)$ (Tables 2 and 3 ). This means that the model does not explain most of data variability. For this reason, only the $\mathrm{R}^{2}$ from the quadratic models are presented, together with the P-values of the analysis of variance (Tables 2 and 3 ). Dietary taurine supplementation did not affect fish growth, consumption and feed efficiency (Table 2). Hemoglobin and hematocrit concentrations did not differ among treatments (Table 3). The triglyceride value was higher for the fish fed the $0.5 \%$ taurine diet compared to the diet with no taurine supplementation (Table 3). Glucose, total protein, cholesterol and albumin did not differ among treatments (Table 3).

\section{DISCUSSION}

Methionine is the first limiting amino acid in plant proteins that plays a key role in cysteine and taurine production (NRC 2011). Studies have shown a wide divergence in the pathway and biosynthesis capacity of taurine according to fish species, fish development phase and diet composition (El-Sayed 2014). In freshwater fish, taurine supplementation appears to be conditionally essential when diet lacks methionine. Juveniles of largemouth bass, Micropterus salmoides fed on a fishmealbased diet $(0.17 \%$ taurine) or a pork residue meal-based diet to replace fishmeal $(0.02 \%$ taurine) presented no increased growth after including 2\% dietary taurine (Frederick et al. 2016). Similarly, common carp, Cyprinus carpio were fed diets containing fishmeal as the protein source $(0.06 \%$ taurine $)$ and 
Table 2. Growth performance of juvenile pirarucu, Arapaima gigas fed different taurine supplementation levels in diet for 28 days $(n=3$ replicates per treatment).

\begin{tabular}{|c|c|c|c|c|c|c|c|}
\hline & \multicolumn{5}{|c|}{ Taurine supplementation levels (\%) } & \multirow{2}{*}{$P$-value } & \multirow{2}{*}{$\left(R^{2}\right)^{*}$} \\
\hline & 0 & 0.5 & 1.0 & 1.5 & 3.0 & & \\
\hline Survival (\%) & 100 & 100 & 100 & 100 & 100 & - & - \\
\hline Weight gain (g) & $121.04 \pm 9.28$ & $131.38 \pm 1.60$ & $117.02 \pm 16.14$ & $119.82 \pm 4.65$ & $111.22 \pm 11.89$ & 0.25 & 0.22 \\
\hline Daily weight gain (g day ${ }^{-1}$ ) & $4.33 \pm 0.33$ & $4.70 \pm 0.06$ & $4.18 \pm 0.58$ & $4.28 \pm 0.17$ & $4.00 \pm 0.42$ & 0.25 & 0.22 \\
\hline Specific growth rate $\left(\%\right.$ day $\left.^{-1}\right)$ & $6.80 \pm 0.26$ & $7.13 \pm 0.08$ & $6.70 \pm 0.42$ & $6.8 \pm 0.13$ & $6.6 \pm 0.28$ & 0.19 & 0.24 \\
\hline Feed consumption (g) & $105.57 \pm 13.92$ & $117.13 \pm 11.01$ & $101.90 \pm 9.82$ & $107.03 \pm 11.42$ & $110.22 \pm 25.89$ & 0.85 & 0.06 \\
\hline Feed conversion ratio & $0.87 \pm 0.07$ & $0.89 \pm 0.09$ & $0.87 \pm 0.05$ & $0.89 \pm 0.12$ & $0.98 \pm 0.12$ & 0.13 & 0.36 \\
\hline Protein efficiency ratio & $2.37 \pm 0.19$ & $2.28 \pm 0.24$ & $2.30 \pm 0.13$ & $2.28 \pm 0.28$ & $2.06 \pm 0.24$ & 0.20 & 0.23 \\
\hline
\end{tabular}

"Coefficient of determination from quadratic model of polynomial regression analysis.

Table 3. Blood variables of juvenile pirarucu, Arapaima gigas fed different taurine supplementation levels for 28 days ( $\mathrm{n}=15$ fish per treatment).

\begin{tabular}{|c|c|c|c|c|c|c|c|}
\hline & \multicolumn{5}{|c|}{ Taurine supplementation levels (\%) } & \multirow{2}{*}{$P$-value } & \multirow{2}{*}{$\left(R^{2}\right)^{*}$} \\
\hline & 0 & 0.5 & 1.0 & 1.5 & 3.0 & & \\
\hline Hemoglobin $\left(\mathrm{g} \mathrm{dL}^{-1}\right)$ & $10.14 \pm 0.08$ & $10.44 \pm 0.28$ & $10.02 \pm 0.46$ & $10.53 \pm 0.66$ & $10.00 \pm 0.34$ & 0.67 & 0.06 \\
\hline Hematocrit (\%) & $27.20 \pm 1.40$ & $28.73 \pm 0.82$ & $26.13 \pm 1.91$ & $28.37 \pm 0.78$ & $28.63 \pm 1.58$ & 0.41 & 0.06 \\
\hline Glucose (mg dL-1) & $49.77 \pm 9.78$ & $45.17 \pm 9.40$ & $55.25 \pm 1.02$ & $51.31 \pm 14.63$ & $63.76 \pm 6.74$ & 0.48 & 0.22 \\
\hline Total plasma protein $\left(\mathrm{g} \mathrm{dL}^{-1}\right)$ & $2.88 \pm 0.13$ & $3.07 \pm 0.22$ & $2.91 \pm 0.11$ & $3.29 \pm 0.12$ & $3.23 \pm 0.21$ & 0.17 & 0.27 \\
\hline Cholesterol (mg dL $\left.{ }^{-1}\right)$ & $100.91 \pm 10.22$ & $116.77 \pm 13.77$ & $113.75 \pm 7.60$ & $119.71 \pm 3.34$ & $132.31 \pm 9.23$ & 0.12 & 0.34 \\
\hline Triglycerides (mg dL $\mathrm{L}^{-1}$ ) & $93.97 \pm 4.92^{b}$ & $133.75 \pm 17.81^{\mathrm{a}}$ & $117.77 \pm 1.33^{\mathrm{ab}}$ & $123.01 \pm 4.08^{\mathrm{ab}}$ & $102.68 \pm 5.65^{\mathrm{ab}}$ & 0.02 & 0.28 \\
\hline Albumin $\left(\mathrm{g} \mathrm{dL}^{-1}\right)$ & $1.06 \pm 0.18$ & $1.20 \pm 0.09$ & $1.63 \pm 0.04$ & $1.29 \pm 0.60$ & $1.36 \pm 0.18$ & 0.49 & 0.13 \\
\hline
\end{tabular}

a,b Different superscript letters in the same row indicate significant differences $(P<0.05)$.

* Coefficient of determination from quadratic regression analysis.

they did not show any increase in growth and feed efficiency when $1 \%$ and $3 \%$ taurine were added (Kim et al. 2008). In both cases, the methionine levels were probably sufficient for taurine biosynthesis. Dietary taurine supplementation of $0.45 \%$ promoted methionine-sparing effect for Nile tilapia, Oreochromis niloticus fed a methionine-deficient soy-based diet. However, it did not improve growth when diet was supplied with adequate methionine levels (Michelato et al. 2018). Similarly, the inclusion of approximately $0.5 \%$ of taurine in a methionine-deficient diet improved growth of rainbow trout, Oncorhynchus mykiss (Gaylord et al. 2006) as well as the protein utilization efficiency of barramundi, Lates calcarifer (Poppi et al. 2018). Taurine supplementation neither significantly improved the growth of juvenile pirarucu nor caused any deleterious effect. Apparently, commercial basal diet levels of $1.13 \%$ methionine and $0.18 \%$ taurine sufficed to allow satisfactory growth of this species. In fact, the methionine level of the tested commercial basal diet was adequate to the methionine requirement (approximately $0.85 \%$ of diet for a $45 \%$ crude protein diet) estimated for juvenile pirarucu based on the muscle tissue amino acid profile (Rodrigues et al. 2017).

Atlantic salmon, Salmo salar fed on a diet with a suboptimal methionine level and taurine deficiency showed an increase in the hepatosomatic index and a higher triglycerides concentration in the liver with no negative effect on growth performance (Espe et al. 2010). These authors suggested that this increase was due to a lower bile acid concentration in the fish (probably due to reduced taurine biosynthesis), which would promote an increase in lipogenesis. Similarly, the plasma triglyceride levels of Japanese flounder, Paralichthys olivaceus were higher in the fish fed low-taurine diets compared to those receiving this nutrient supplementation, whose diet inclusion positively influenced fish growth and feed intake (Han et al. 2014). Hoseini et al. (2018), however, reported an increase in serum triglycerides of Persian sturgeon, Acipenser persicus supplemented with taurine. These authors concluded that further studies were needed to elucidate the role of taurine in lipid transport in fish. This increase was also observed in the present study for the pirarucu supplemented with $0.5 \%$ taurine. As it was a one-time variation in the $0.5 \%$ taurine diet, it is possible that it does not represent a taurine-influenced response and requires further investigation.

For some fish species, taurine apparently acts on glycemic control by lowering plasma glucose levels and affecting cholesterol metabolism by stimulating its production (Maita et al. 2006; Han et al. 2014; Watson et al. 2014; Hoseini et al. 2018). Dietary taurine supplementation did not affect 
pirarucu blood glucose values. For cholesterol, although nonsignificant, plasma cholesterol levels tended to increase when higher levels of taurine were included in the $\operatorname{diet}(\mathrm{P}=0.12)$.

Hematimetric indices are important parameters for assessing the oxidative status of fish (Menezes et al. 2006). Supplementation of $0.08 \%$ taurine in a plant protein-based diet improved the immune resistance of yellowtail, Seriola quinqueradiata by elevating hematocrit values and minimizing fish anemia signs (Maita et al. 2006). The cited authors related this result to the antioxidant role of taurine, which suggests that oxidation and damage to membrane stability induced by taurine deficiency may lead to erythrocyte destruction. In the present work, taurine supplementation did not alter the hemoglobin and hematocrit values of fish, which indicates that the taurine and methionine levels in the basal diet were adequate for pirarucu. Considering that the fish in our trial exhibited a high specific growth rate with low feed conversion, the hematimetric and physiological parameter values obtained herein may be useful to support future studies that also evaluate the variation of these variables in pirarucu.

\section{CONCLUSIONS}

Our results indicate that the amount of $0.18 \%$ of taurine in a diet containing $1.13 \%$ of methionine sufficed to promote adequate juvenile pirarucu growth with no variation in its main blood physiological parameters. Further studies to assess whether taurine supplementation is conditionally essential for pirarucu fed methionine-deficient diets are needed to elucidate the functionality of this nutrient for this species.

\section{ACKNOWLEDGMENTS}

The present study is part of the "Pirarucu da Amazônia Project - Research and Technology Transfer" ("Projeto Pirarucu-da-Amazônia - Pesquisa e Transferência de Tecnologias"), funded by Serviço Brasileiro de Apoio às Micro e Pequenas Empresas (SEBRAE) through Fundação de Apoio Científico e Tecnológico do Tocantins (FAPTO) (agreement 9/2012, grant no. 2538/2012) and Ministério da Agricultura, Pecuária e Abastecimento, through Conselho Nacional de Desenvolvimento Científico e Tecnológico (CNPq) (grant no. 434.400/2016-5). This work was also supported by Coordenação de Aperfeiçoamento de Pessoal de Nível Superior (CAPES) (grant no. 88881.068171/2014-01).

\section{REFERENCES}

AOAC. 1990. Official Methods of Analysis. 15th ed. Association of Official Analytical Chemists, Arlington, 1422p.

Blaxhall, P.C.; Daisley, K.W. 1973. Routine hematological methods for use with fish blood. Journal of Fish Biology, 5: 771-781.

Carvalho, C.; Power, M.; Forsberg, B.R.; Castello, L.; Martins, E.G.; Freitas, C.E.C. 2018. Trophic ecology of Arapaima sp. in a ria lake - river - floodplain transition zone of the Amazon. Ecology of Freshwater Fish, 27: 237-246.

Cavero, B.A.S.; Ituassú, D.R.; Pereira Filho, M.; Roubach, R.; Bordinhon, A.M.; da Fonseca, F.A.L.; Ono, E.A. 2003a. Uso de alimento vivo como dieta inicial no treinamento alimentar de juvenis de pirarucu. Pesquisa Agropecuária Brasileira, 38: 1011-1015.

Cavero, B.A.S.; Pereira-Filho, M.; Roubach, R.; Ituassú, D.R.; Gandra, A.L.; Crescêncio, R. 2003b. Efeito da densidade de estocagem na homogeneidade do crescimento de juvenis de pirarucu em ambiente confinado. Pesquisa Agropecuária Brasileira, 38: 103-107.

Cyrino, J.E.P.; Bicudo, A.J.A.; Sado, R.Y.; Borghesi, R.; Dairiki, J.K. 2010. A piscicultura e o ambiente - o uso de alimentos ambientalmente corretos em piscicultura. Revista Brasileira de Zootecnia, 39: 68- 87.

El-Sayed, A.-F.M. 2014. Is dietary taurine supplementation beneficial for farmed fish and shrimp? A comprehensive review. Reviews in Aquaculture, 6: 241-255.

Espe, M.; Rathore, R.M.; Du, Z-Y.; Liaset, B.; El-Mowafi, A. 2010. Methionine limitation results in increased hepatic FAS activity, higher liver 18:1 to 18:0 fatty acid ratio and hepatic TAG accumulation in Atlantic salmon, Salmo salar. Amino Acids, 39: 449-460.

Farias, I.P.; Leão, A.; Almeida, Y.S.; Verba, J.T.; Crossa, M.; Honczaryk, A.; Hrbek, T. 2015. Evidence of polygamy in the socially monogamous Amazonian fish Arapaima gigas (Cuvier, 1817). Neotropical Ichthyology, 13: 195-204.

Frederick, C.A.; Coyle, S.D.; Durborow, R.M.; Bright, L.A.; Tidwell, J.H. 2016. Effect of taurine supplementation on growth response and body composition of largemouth bass. North American Journal of Aquaculture, 78: 107-112.

Gaylord, T.G.; Teague, A.M.; Barrows, F.T. 2006. Taurine supplementation of all-plant protein diets for rainbow trout (Oncorhynchus mykiss). Journal of the World Aquaculture Society, 37: 509-517.

Gaylord, T.G.; Barrows, F.T.; Teague, A.M.; Johansen, K.A.; Overturf, K.E.; Shepherd, B. 2007. Supplementation of taurine and methionine to all-plant protein diets for rainbow trout (Oncorhynchus mykiss). Aquaculture, 269: 514-524.

Goldenfarb, P.B.; Bowyer, F.P.; Hall, E. 1971. Reproducibility in the hematology laboratory: the microhematocrit determination. American Journal of Clinical Pathology, 56: 35-39.

Gormley, T.R.; Neumann, T.; Fagan, J.D.; Brunton, N.P. 2007. Taurine content of raw and processed fish fillets/portions. European Food Research Techonology, 225: 837-842.

Han, Y.; Koshio, S.; Jiang, Z.; Ren, T.; Ishikawa, M.; Yokoyama, S.; Gao, J. 2014. Interactive effects of dietary taurine and glutamine on growth performance, blood parameters and oxidative status of Japanese flounder Paralichthys olivaceus. Aquaculture, 434: 348-354.

Hoseini, S.M.; Eskandari, S.A.H.S.; Amirahmadi, M. 2018. Effect of dietary taurine and methionine supplementation on growth performance, body composition, taurine retention and lipid status of Persian sturgeon, Acipenser persicus (Borodin, 1897), fed with plant-based diet. Aquaculture Nutrition, 24: 324-331. 
Huxtable, R.J. 1992. Physiological actions of taurine. Physiological Reviews, 72: 101-163.

Kim, S.-K.; Matsunari, H.; Takeuchi, T.; Yokoyama, M.; Furuita, H.; Murata, Y.; Goto, T. 2008. Comparison of taurine biosynthesis ability between juveniles of Japanese flounder and common carp. Amino Acids, 35: 161-168.

Lim, S.; Oh, D.; Khosravi, S.; Cha, J.; Park, S.; Kim, K.; Lee, K. 2013. Taurine is an essential nutrient for juvenile parrot fish Oplegnathus fasciatus. Aquaculture, 414-415: 274-279.

Lima, A.F.; Rodrigues, A.P.O.; Varela, E.S.; Torati, L.S.; Maciel, P.O. 2015. Pirarucu culture in the Brazilian Amazon. Fledgling industry faces technological issues. Global Aquaculture Advocate, 18: $56-58$.

Maita, M.; Maekawa, J.; Satoh, K.; Futami, K.; Satoh, S. 2006. Disease resistance and hypocholesterolemia in yellowtail Seriola quinqueradiata fed a non-fishmeal diet, Fisheries Science, 72: 513-519.

Menezes, G.C.; Tavares-Dias, M.; Ono, E.A.; Andrade, J.I.A.; Brasil, E.M.; Roubach, R.; Urbinati, E.C.; Marcon, J.L.; Affonso, E.G. 2006. The influence of dietary vitamin $\mathrm{C}$ and $\mathrm{E}$ supplementation on the physiological response of pirarucu, Arapaima gigas, in net culture. Comparative Biochemistry and Physiology, Part A, 145: 274-279.

Michelato, M.; Furuya, W.M.; Gatlin, D.M. 2018. Metabolic responses of Nile tilapia Oreochromis niloticus to methionine and taurine supplementation. Aquaculture, 485: 66-72.

NRC. 2011. Nutrient Requirements of Fish and Shrimp. National Research Council, The National Academies Press, Washington, DC, 376p.

Núñez, J.; Chu-Koo, F.; Berland, M.; Arévalo, L.; Ribeyro, O.; Duponchelle, F.; Renno, J.F. 2011. Reproductive success and fry production of the paiche or pirarucu, Arapaima gigas (Schinz), in the region of Iquitos, Perú. Aquaculture Research, 42: 815-822.

Oliveira, V.; Poleto, S.L; Venere, P.C. 2005. Feeding of juvenile pirarucu (Arapaima gigas, Arapaimidae) in their natural environment, lago Quatro Bocas, Araguaiana-MT, Brazil. Neotropical Ichthyology, 3: 312-314.
Peterson, B.C.; Li, M.H. 2018. Effect of supplemental taurine on juvenile channel catfish Ictalurus punctatus growth performance. Aquaculture Nutrition, 24: 310-314.

Poppi, D.A.; Moore, S.S.; Glencross, B.D. 2018. The effect of taurine supplementation to a plant-based diet for barramundi (Lates calcarifer) with varying methionine content. Aquaculture Nutrition, 24: 1340-1350.

Queiroz, H.L. 2000. Natural history and conservation of pirarucu, Arapaima gigas, at the Amazonian varzea: red giants in muddy waters. Doctoral thesis, University of St. Andrews, UK. 226p. ( https://research-repository.st-andrews.ac.uk/ handle/10023/2818)

Rodrigues, A.P.O.; Freitas, L.E.L.; Santos, V.R.V.; Moro, G.V.; Honda, R.T.; Araujo, P.L.D.; Bicudo, A.J.A. 2017. Qualidade de Raçôes Comerciais Utilizadas na Alimentação do Pirarucu Arapaima gigas em Cativeiro. Boletim de Pesquisa e Desenvolvimento, nr. 23, Embrapa Pesca e Aquicultura Palmas, 21p.

Rodrigues, A.P.O.; Lima, A.F.; Andrade, C.L.; Medeiros, R.M.S 2019. Feeding frequency affects feed intake and growth in juvenile pirarucu (Arapaima gigas). Acta Amazonica, 49: 11-16.

Salze, G.P.; Davis, D.A. 2015. Taurine: a critical nutrient for future fish feeds. Aquaculture, 437: 215-229.

Spitze, B.A.R.; Wong, D.L.; Rogers, Q.R.; Fascetti, A.J. 2003. Taurine concentrations in animal feed ingredients; cooking influences taurine content. Journal of Animal Physiology and Animal Nutrition, 87: 251-262.

Watson, A.M.; Barrows, F.T.; Place, A.R. 2014. Effects of graded taurine levels on juvenile cobia. North American Journal of Aquaculture, 76: 190-200.

White, J.; Hart, R.; Fry, J. 1986. An evaluation of the waters pico-tag system for the amino-acid-analysis of food materials. Journal of Automatic Chemistry, 8: 170-177.

RECEIVED: $21 / 11 / 2019$

ACCEPTED: $12 / 08 / 2020$

ASSOCIATE EDITOR: Rodrigo R. do Valle 